About two thirds of the book is devoted to an examination of the possibilities of shaping population policies, of developing social control of the economic system, of reconstructing international and racial relations, and of fitting government, the family, moral codes, education, and religion to changing social needs.

The author brings a humane and realistic scholarship to a task which he handles in a spirit at once conservative and forward looking. The book should prove useful to the general reader as well as to college students in sociological classrooms.

\section{Dartmouth College}

\section{Ervilue B. Woons}

Cantor, Nathantal F. (Introduction by Raymond Moley.) Crime:Criminals and Criminal Justice. Pp. xiv, 470. New York: Henry Holt \& Company, 1932. \$3.50. Students' edition, \$2.80.

This volume is another brave attempt at a synthesis of the many and varied subjects that fall within the field of criminology. It gets off to a good start with an encouraging introduction by Professor Raymond Moley. The spirit of the volume is both expository and polemical, though caution is displayed in the selection of materials, and in the assertion of opinion where the evidence is partially lacking. In general, one gets the impression that the volume is both sound and formidable.

The materials are arranged under five major categories, of which the first is entitled "Perspectives." This word could suggest almost anything germane to the general subject, but the author uses it here to include subject matter relating to the place of criminology among the social sciences, and to the modern efforts toward a new orientation of the law as an empirical science. On the former point there is sound discussion of the qualitative differences between the natural and the social sciences both as to subject matter and as to method; and on the latter point, there is a justifiable animus against those still prevailing tendencies in the law which make it cling to outworn historical precedents, or to psychological or other assumptions that cannot possibly square with our new scientific insights. In general, it seems that the author is strongly affected by the juridical aspects of the subject, which are developed somewhat at the expense of his sociological data.

This last point is demonstrated by the fact that in Part II on "The Making of the Criminal Mind," the author compresses within three chapters most of the evidence of a sociological or psychological character that bears upon the genesis of crime. Herein is presented in a fragmentary manner some of the recent data relating to the alleged "causes" of crime and delinquency. No doubt Dr. Cantor is right in his conten. tion that our knowledge of the causes of crime is lacking in specificity and conclusiveness. What we have are general hunches such as a good surgeon gets through feeling over the body of the patient. We can locate the source of trouble, but have no techniques, as the surgeon has, for putting our fingers surely and precisely upon the difficulty. But where the author is cautious and skeptical on these matters, at another turn of the discussion he rises to dogmatic certainty when he says: "So long as the Western European economic order remains fundamentally unaltered, there is little likelihood of controlling in any large measure the complex factors generating crime and criminals." I am inclined to agree with this statement, and I am glad to see such an emphasis made. But on the other hand I would give more credence than the author seems to give to the conclusions that are made in some of the recent studies of juvenile delinquency relative to the bearing of family life and of neighborhood and economic conditions upon juvenile crime.

Where the author's skepticism is greatest is in his discussion of the relationship of psychopathology to crime. With regard both to mental deficiency and to the various categories of mental disorder, Dr. Cantor feels that our knowledge of their precise bearing upon the problem of crime in general is hazy and uncertain. The psychiatrists are accused, with some degree of justification, of falling into the fallacy that Lombroso embraced, of an attempt to create a criminal type without adequate reference to control groups.

In Part III under the heading of "The 
Administration of Criminal Justice" there are six chapters which run the gamut of the legal procedures from the time of the arrest or complaint to the disposition of the case in court. The author has drawn heavily upon the recent critical materials from some of the crime commissions and from awakened legal authorities to indicate the "cultural lag" in existing criminal procedures. The familiar picture is drawn of our legal agencies proceeding against the citadels of crime, not as a well-disciplined army which acts from common agreement as to first principles, but as a Falstaffian crew, armed with archaic weapons, amid a confusion of voices as to what should be done. Dr. Cantor holds forth little hope of improvement from a piecemeal remedy of the system, but looks for permanent results only through a new legal philosophy based upon empirical science, and a more effective support for public administration which would derive its methods and principles from such a new, scientific orientation.

Nine chapters ensue under the general heading of "Penology." There is a Darrow-like attack upon the assumption of individual responsibility in a deterministic universe; and although the author affirms that the mechanisms of human behavior operate on a different plane from the materials in a test tube, he does not make clear just what, if anything, the individual has to do with his own destiny.

In his discussion of the penal system, its defects are effectively portrayed. There is a commendable amount of factual material relative to developments and conditions in the American penal system, including an account of many progressive measures already adopted. There is also a valuable chapter on the legal status of the prisoner, and an evaluation of the scientific attempts that have been made by Professor Burgess and by the Gluecks to predict the effect of parole.

A final section under the somewhat dubious title of "Techniques" has three chapters which demonstrate the paucity of our statistical materials; set forth what the author calls "Root Problems"; and present a valuable account of the penal system in Soviet Russia. His "Root Problems" select rather arbitrarily nine important phases of the general problem of crime from eugenics to the reform of the economic system. One feels that an equally imposing list of nine other factors might have been enumerated with quite as much validity. One of his "Root Problems" is religion, but this is disposed of in a paragraph which presents two diametrically opposed views as to the effect of religion, leaving us unenlightened as to whether or not it is a problem at all.

One comes to the end of this good book with the thought that another wedge has been put under the ponderous bulk of our respectable and ancient penal system, including its concepts and procedures.

\section{University of Michigan}

Arthur Evans Wood

Ettinger, Clayton J. The Problem of Crime. Pp. viii, 538. New York: Raj Long \& Richard R. Smith, Inc., 1932. $\$ 3.00$.

Dr. Ettinger is both a psychiatrist and a professional sociologist. $\mathrm{He}$ is a doctor of medicine from the Detroit College of Medicine and Surgery, and received his Ph.D. from the University of Pittsburgh. He has also been a graduate student at Columbia, the Sorbonne, and Cambridge. At present he is professor of sociology at Western State Teachers College, Kalamazoo, Michigan, and visiting psychiatrist at the Kalamazoo State Hospital. With such qualifications, one might readily believe that the textbook in criminology had finally been written. Unfortunately, the content of the book fails to reflect the excellent orientation and training which the author undoubtedly possesses.

The book is divided into three parts: Part I is devoted to "The Criminal," and covers twelve chapters, two of which are analyses of psychiatric factors and one of which analyzes the influence of alcohol and narcotic drugs. Part II is devoted to "The Machinery of Justice," four chapters describing methods in crime detection, the police system, criminal law and procedure, and the juvenile court. Part III, consisting of eleven chapters and entitled "Society's Reaction to the Criminal," describes the development of penology, contemporary prison conditions, and the techniques and 